This is an electronic reprint of the original article. This reprint may differ from the original in pagination and typographic detail.

Author(s): Ojala, Arto

Title: Geographic, cultural, and psychic distance to foreign markets in the context of small and new ventures

Year: $\quad 2015$

Version:

Please cite the original version:

Ojala, A. (2015). Geographic, cultural, and psychic distance to foreign markets in the context of small and new ventures. International Business Review, 24 (5), 825-835. doi:10.1016/j.ibusrev.2015.02.007

All material supplied via JYX is protected by copyright and other intellectual property rights, and duplication or sale of all or part of any of the repository collections is not permitted, except that material may be duplicated by you for your research use or educational purposes in electronic or print form. You must obtain permission for any other use. Electronic or print copies may not be offered, whether for sale or otherwise to anyone who is not an authorised user. 


\title{
Geographic, Cultural, and Psychic Distance to Foreign Markets in the Context of Small and New Ventures
}

\author{
Arto Ojala \\ University of Jyväskylä
}

\begin{abstract}
More often than one might expect, small and new ventures, which already suffer from few resources and a lack of industry legitimacy, take on the additional uncertainties of entry into foreign markets. Some of these foreign entries involve countries that are geographically distant and culturally different from the firm's home country, making foreign market entry all the more difficult and uncertain. Recent studies have criticized prior academic approaches to understanding these difficulties. Insights may be limited if one uses merely the concept of distance and looks primarily for main effects. Entry by new and small ventures into distant foreign markets is complex, and the factors influencing it are interactive. The aim of this conceptual paper is to contribute to an understanding of the stability of the distance factors, and also the interactive effects between distance factors, market attractiveness, and network relationships, with particular attention to small and new ventures.
\end{abstract}

Keywords: Geographic distance, cultural distance, psychic distance, foreign market entry, small and new ventures, network relationships 


\section{Introduction}

More than a decade ago Shenkar (2001) highlighted a variety of problems with "cultural distance" as a useful metaphor in research on international business. Among other remedies he proposed "friction" between cultures as a better metaphor than "distance" on the grounds that it emphasizes the contact between cultures and the possibility of conflict. Later, Shenkar et al. (2008) argued more strongly for friction as a metaphor, noting that conflicts are likely when distinctive cultures interact, and also that large corporations often use power to manage these conflicts. Similar questions have been raised regarding psychic distance, its validity, and its usage in international business. Some scholars have argued that psychic distance is a concept that is past its due date (Stöttinger and Schlegelmilch, 2000) or concluded that it is not a valid concept for small and new ventures (Autio, 2005; Bell et al., 2001). Nonetheless, the concepts of cultural and psychic distance continue to be used metaphorically by international business scholars (Ambos and Håkanson, 2014; Dow and Karunaratna, 2006; Håkanson and Ambos, 2010; Mezias et al., 2002). Thus, it can be argued that international business research on distance should not be abandoned, but rather refined.

Despite criticisms and disagreements, several scholars have contributed to our understanding of cultural distance, and of other types of distance - specifically, geographical and psychic distance. These studies have mainly focused on how distances impact on firms' international expansion. Recently, scholars have also deepened our understanding on the nature of the distances themselves (Nebus and Chai, 2014), and distinguished differences between the distances in question (Håkanson and Ambos, 2010). Indeed, research has indicated that many common assumptions regarding distance are incorrect and require further investigation (Avloniti and Filippaios, 2014; Håkanson and Ambos, 2010; Ellis, 2008; Shenkar, 2001; Nebus and Chai, 2014). Despite this, all studies on the topic agree that when 
the distance between a home and a target country becomes greater, this increases the uncertainty of doing business.

Especially for small and new ventures, this uncertainty is critical. Unlike large established corporations, small organizations have relatively few resources to devote to internationalization (Oviatt and McDougall, 1994) or to transform competitive advantages in such a way as to overcome the difficulties created by distance dimensions (Nebus and Chai, 2014). Small and new ventures have relatively weak legitimacy in their industries and among potential customers, in both their home markets and foreign markets. The managers of these small and new ventures are often inexperienced at international business. Securing entry into distant foreign countries is particularly uncertain for such organizations; consequently, every action they take in a distant location has significance for their survival (Bell et al., 2003; Coviello, 2006; Oviatt and McDougall, 1994). It should also be noted that these firms have received less research attention than large multinational corporations (MNCs), and that their typically weak power to dictate terms in host-country cultures may contrast in interesting ways with the power that Shenkar et al. (2008) depict in their discussion of established multinationals. Thus, studying geographic, cultural, and psychic distance in small and new ventures may yield evidence that is more interesting than would be the case if the research focused on established MNCs.

With these considerations in view, the aim of this paper is to contribute to a theoretical understanding of the dimensions termed geographical, cultural, and psychic distance, looking at how they affect small and new ventures. The focus of the paper is on the stability of the distance factors and on the interactive effects between distance factors, market attractiveness, and network relationships. It is true that distance factors have received considerable attention among international business scholars; nevertheless, the stability of these factors has been largely neglected. Thus, we adhere to Shenkar's (2001) argument 
concerning the illusion of stability. A second aspect to note is that the roles of market attractiveness and network relationships have been seen as having an impact on distance factors (Johanson and Vahlne, 2009; Ojala, 2009). However, important questions remain as to precisely how distance factors interact with market attractiveness (cf. Ellis, 2008) and network relationships (cf. Johanson and Vahlne, 2009).

We begin with a focus on the three dimensions of distance mentioned above and their impact on the foreign market entry of small and new ventures. This is followed by discussion on the factors that make a foreign market attractive, and how the attractiveness of a foreign market interacts with distance. Thereafter, we address the interactive role of distance dimensions with foreign market size, considering also the stability of distance, and the interactive role of network relationships. Our approach makes it possible to delineate testable propositions for further studies on distance. At the end of the paper, we discuss the measurement of different distance dimensions.

\section{Three Dimensions of Distance}

In the context of this study, distance dimensions can be divided into geographic, cultural, and psychic distance. These are in fact the three concepts most commonly used in the literature on international business (e.g., Brewer, 2007; Child et al., 2009; Dow, 2000; Dow and Karunaratna, 2006; Ellis, 2008; Ojala and Tyrväinen, 2007, 2008; Ragozzino, 2009). However, we also acknowledge certain distance concepts that have received attention more recently. For instance, $\mathrm{Xu}$ and Shenkar (2002) focused on how institutional distance affects foreign direct investment by multinational enterprises, while Peretto and Smulders (2002) investigated how technological distance reduces the spillovers between firms. Estrin et al. (2009) examined how human resource distance impacts on the entry mode choices of 
multinational enterprises. Some scholars have stressed the existence of multiple distance dimensions, referring to important simultaneous influences on international firm behavior. Ghemawat (2001) highlighted the commercial effects of cultural, administrative, geographic, and economic distance among countries. Shenkar (2001) identified many additional dimensions, including for example linguistic, religious, educational, and political factors. All in all, there would seem to be quite a number of factors that can impact on the international activities of firms, especially small and new ventures. Nevertheless, for the sake of conciseness and clarity, we shall concentrate here on the most commonly used distance dimensions: geographic, cultural, and psychic distance. It should be noted that several studies have used psychic distance as a first order construct that includes several of the dimensions listed above (see e.g., Brewer, 2007; Dow and Karunaratna, 2006; Håkanson and Ambos, 2010).

An examination of foreign distance in terms of three dimensions - physical space, socio-cultural norms, and perceptual issues - makes it possible to achieve extensive coverage of the main foreign distance concepts that interest scholars of international business. It also addresses some of the problems brought about by restricting oneself to a single "distance" metaphor (Shenkar, 2001). It should be noted that none of the points made above denies the importance of "cultural friction," bearing in mind that the latter concept, although related to and affected by distance, is of a different nature (Luo and Shenkar, 2011; Shenkar et al., 2008). Cultural distance is an "ambient condition" that may or may not result in friction, depending on a variety of other influences, such as the quality of communication between foreign firms and the people in a host country (Luo and Shenkar, 2011). Most importantly, defining and distinguishing between geographic, cultural, and psychic distance highlights for scholars the necessity of having fully worked out theoretical development if one is to understand how the dimensions of international distance operate. We believe that attention to 
the precise distinctions in question provides the best chance of yielding significant and meaningful empirical results.

\subsection{Geographic distance}

Geographic distance is the physical separation between one location and another, typically involving the space between the home of a firm and the foreign location in which it is selling, or exploring possible sales. Increasing the physical space, as measured in kilometers or miles between countries or cities, or between a firm and its market, adds time and costs to commercial transactions, thus making the market less attractive in terms of efforts to increase sales (Dunning, 2001).

Lower economic and managerial costs, rapid and effective information exchange, and environmental familiarity are all important reasons why geographically proximate countries attract mutual entry. Recent improvements in transportation systems and communication technologies, including the Internet, have not eliminated the influence of geographic distance on trade intensity between countries (Dow, 2000; Dow and Karunaratna, 2006; Ghemawat, 2001; Gooris and Peeters, 2014; Leamer and Storper, 2001) or its impact for small and new ventures (Brock et al., 2011; Dow, 2000). Geographic distance even impacts on the trade of digital goods sold over the Internet (Blum and Goldfarb, 2006), affecting the market selection of small software firms that trade completely intangible products (Ojala and Tyrväinen, 2007, 2008).

It seems that the impact of geographic distance on the foreign market selected decreases after initial market entry (Clark and Pugh, 2001; Ojala and Tyrväinen, 2007). Clark and Pugh (2001) found that the first three countries entered by British firms were geographically closer than the last three countries. Ojala and Tyrväinen (2007) found that the 
entry priority of small software firms tended to shift from geographically close countries (first and second entries) to geographically more distant countries (third entry). There are several reasons why small and new ventures tend to enter nearby markets first. In addition to the likelihood that these firms will have relatively fewer resources than MNCs (Oviatt and McDougall, 1994), nearby markets may offer quick access to funding opportunities (Freeman et al., 2012), and better possibilities to build networks for further business opportunities (cf. Coviello, 2006; Freeman et al., 2012; Johanson and Vahlne, 2009).

\subsection{Cultural distance}

The terms cultural distance and psychic distance are often used interchangeably, or without much thought to their possible differences (Håkanson and Ambos, 2010). In fact, recent literature on international business has highlighted several differences between the terms and concluded that cultural distance is only one, albeit important, component of the wider concept of psychic distance (Dow and Karunaratna, 2006; Håkanson and Ambos, 2010; Sousa and Lages, 2011). Despite this, the cultural distance dimension has been used widely in international business literature as a single construct influencing firms' international expansion (Håkanson and Ambos, 2010).

There is general agreement that "culture" refers broadly to the collection of assumptions, values, and normative behaviors of a group of people (Leung et al., 2005). There are many studies on how cultural distance between groups in various countries affects foreign entry and trade in negative ways (Shenkar, 2001). Examples include studies on differences in values between people (Hofstede, 1980, 2001; House et al., 1999; Schwartz, 1994), on differences in communication style (Hall and Hall, 1990), and on cultural stereotypes (Gannon, 1994). 
Overall, "cultural distance" can be seen as referring to the differences between groups of people regarding values, communication styles, and stereotypes. By contrast, "psychic distance" refers to an actor's perceptions of a foreign country. Imprecision in the concepts applied is one reason why empirical explorations of national cultural distance (looking at individual-level phenomena) have shown conflicting results (Avloniti and Filippaios, 2014; Ellis, 2008; Tihanyi et al., 2005) and have brought up conceptual problems (Shenkar, 2001; Shenkar et al., 2008). One problem is that the various measures of culture tap into different assumptions, values, and norms, and that it is often difficult to decide a priori which issue is likely to be most salient in predicting firm behavior (Rothaermel et al., 2006; Shenkar, 2001). A measure of power distance (Hofstede, 1980), for example, will capture a different aspect from a measure of personal space. It is difficult to make general statements about whether differences in either of these aspects contribute to an explanation of why one firm initiates sales in one distant foreign country and not another.

In addition, national cultures within countries are not homogeneous (Avloniti and Filippaios, 2014; Child et al., 2009; Hebdige, 1979; Shenkar, 2001; Williams, 2006); thus, there may well be intra-country differences that have disparate influences on international commerce. For example, cultural values may vary between cosmopolitan cities and rural areas within a country. Child et al. (2009) found that the managers of small UK firms perceived the culture of Sao Paulo to be more familiar than the culture in other parts of Brazil. In addition, Avloniti and Filippainos (2014) found that the intra-cultural diversity within a country is one of the weakest aspects in terms of measuring cultural distance. National cultural indices can give a quantitative summary of some nationwide cultural issues (e.g. Kogut and Singh, 1988) and provide some interesting empirical results; nevertheless, future progress will require researchers to disaggregate such indices, and to develop theories 
about the relationships between specific cultural issues and the behavior of specific groups of people.

In attempts to apply the Kogut and Singh index to Hofstede's cultural dimensions, cultural distance has not proved to be a strong indicator for the internationalization of small and new ventures (Brock et al., 2011; Dow, 2000; Ojala and Tyrväinen, 2007, 2008). However, Kreiser et al. (2010) found that uncertainty avoidance and power distance had a significant and negative impact on the risk-taking level of small and medium-sized enterprises (SMEs). In the case of family SMEs, cultural differences have been found to increase the time needed to build trustful relationships with local partners, with consequent hindrance to business negotiations and the formation of network relationships (Kontinen, 2011; Kontinen and Ojala, 2010). In contrast, MNCs can use their existing networks or financial resources to hire employees with relevant cultural knowledge. For small and new ventures with limited resources and low international experience, this is rarely possible; they have to find other ways to overcome cultural differences (Child et al., 2009; Kontinen, 2011; Ojala, 2009).

\subsection{Psychic distance}

Psychic distance encompasses the disturbance in information flows between organizations and foreign markets caused by actors' perceptions ${ }^{1}$ (Child et al., 2002; Child et al., 2009; Håkanson and Ambos, 2010; Johanson and Wiedersheim-Paul, 1975). It is a first order construct, and one that impacts on actors' perceptions of a foreign country. On the basis of the literature, it would appear to include several dimensions, such as differences in

\footnotetext{
1 The term "psychic distance" has the unfortunate connotation of something supernatural or clairvoyant. Perhaps a better term would be "perceptual distance." However, in order to connect this article with prior research, we adopted the convention of the literature by using the word "psychic," as originally used by Beckerman (1956) and later perpetuated by other scholars.
} 
geography, culture, language, politics, the level of education, the economic situation, the level of industrial development, time zones, and so on (Dow and Karunaratna, 2006; Freeman et al., 2012; Håkanson and Ambos, 2010; Johanson and Wiedersheim-Paul, 1975; Sousa and Lages, 2011). The differences between these dimensions disturb information flow between actors and increase perceived psychic distance; in other words, human awareness, understanding, and perceptions concerning these factors impact on psychic distance (Nebus and Chai, 2014).

Another characteristic of psychic distance is its asymmetrical nature for the buyer and seller. A seller from one country may have a very different degree of understanding of a buyer in a foreign country from that which the buyer has of the seller (Ellis, 2008). For example, a cosmopolitan buyer in Germany may have a better understanding of the likely behavior of a small business owner who sells only in the United States than the American has about the German buyer. Thus, the psychic distance from the German buyer to the American seller is shorter than the reverse distance. Such asymmetrical psychic distance points to important measurement problems in empirical studies. For example, whose psychic distance is salient? Empirical studies rarely consider the issue.

Dow $(2005,17)$ highlights the point that "born-global firms are not immune to psychic distance." In addition to born-globals, many other types of small and new ventures have been reported to have difficulties with psychic distance dimensions. In particular, differences in language have been seen as having a negative effect on the market entry of small and new ventures (Boehe, 2009; Child et al., 2009; Kontinen and Ojala, 2010; Ojala, 2008; Puthusserry et al., 2014). Even in highly globalized industries such as the software industry, language may still prove to be a substantial inhibitor on internationalization (Boehe, 2009; Ojala, 2008; Puthusserry et al., 2014). A number of studies have highlighted how managers of small and new ventures may be forced to use interpreters, recruit foreign 
employees, or find partners with relevant language knowledge (Child et al., 2009; Kontinen and Ojala, 2010; Ojala, 2008). In some cases, they have been obliged to stay in domestic markets and to let MNCs with better resources handle exporting activities (Boehe, 2009).

In relation to institutional distance, Schwens et al. (2011) found that institutional distance impacted on SMEs' choice of entry mode, while prior international experience helped to overcome institutional distance and related risk. However, small and new ventures rarely have prior international experiences. Vachani (2005) found that in fact institutional distance impacted negatively on both large and small firms; nevertheless, small firms may have more problems in coping with institutional distance, since, compared to MNCs, they have less accumulated experience in dealing with international environments, and fewer resources to overcome challenges relating to transferring organizational practices (Vachani, 2005). Political and economic factors may impact negatively on the internationalization decisions made by managers of small and new ventures (Puthusserry et al., 2014). For instance, governmental policies may favor MNCs over small and new ventures, government policies can create an additional bureaucratic burden for small firms, and the financial sector may be more favorable for MNCs (see e.g., Bruton and Rybanik, 2002; Tovstiga et al., 2004).

\section{Foreign market attractiveness and distance}

Several factors motivate firms to initiate foreign commercial activity. These may include obtaining access to essential inputs, finding low-cost means of production, scale economies, and sales growth (Bartlett et al., 2008). The sales revenue derived from exports or other foreign operations has been of interest to many scholars over the years (Autio et al., 2000; Hitt et al., 2006; Sullivan, 1994; Tallman and Li, 1996). Sullivan (1994, 331) argued that "a company's foreign sales are a meaningful first-order indicator of its involvement in 
international business." More than other indicators of internationalization (such as foreign assets or foreign employees), having foreign sales reflects a firm's ability to succeed abroad. Furthermore, recent network approaches to internationalization have shown that the entry mode (which has been a common focus for scholars of international management) is not in fact a reliable indicator of commitment to a foreign market (Johanson and Vahlne, 2009). Thus, if we were to focus purely on foreign entry and ownership through foreign direct investment, we would be overlooking certain important issues related to firm internationalization.

Substantial market size and/or growth are the clearest indicators of significant opportunities for new sales (Bell et al., 2003; Ojala and Tyrväinen, 2007, 2008; Terpstra and $\mathrm{Yu}, 1988)$. This applies to large established corporations and also to small or new ventures, (Bell et al., 2003; Dunning, 2001; Ojala and Tyrväinen, 2007, 2008; Terpstra and Yu, 1988). Bell et al. (2003) argue that rapidly internationalizing knowledge-intensive firms tend to focus on leading markets, such as the U.S. and Japan. Ojala and Tyrväinen (2007, 2008), who examined small and medium-sized software enterprises, found that large foreign market size is the main attraction. Thus, although some small and new ventures tend to focus first on nearby markets because of lower risks and other issues (see e.g. Hashai and Almor, 2004; Wright et al., 2007), throughout this article we shall focus on new ventures and small firms which, in their attention to large markets, have had increased sales in mind.

Additional complexity is introduced when large markets are in distant locations. The difficulty of simultaneously considering market size and market proximity is illustrated in Figure 1. Large size and proximity are two attractive market characteristics that are likely to favor increased sales and reduction of risk. However, if one of these aspects is absent, a market will become less attractive as a sales growth target, and if both are missing, the market may prove unattractive. Thus, market size and market distance interact to influence 
which foreign markets actually attract efforts by small and new ventures to increase their sales revenue.

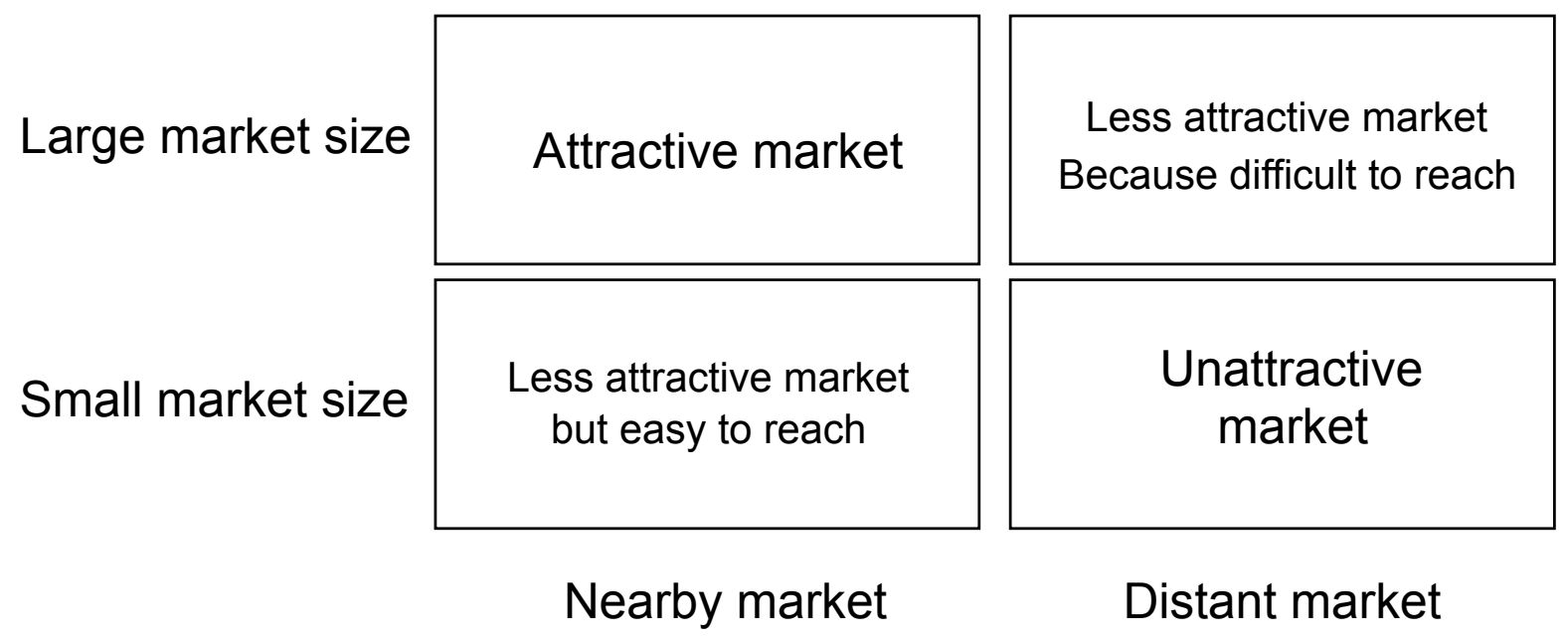

Figure 1. Market size and market distance.

\section{Distance Dimensions and Foreign Market Size}

Ellis (2008) theorized that psychic distance and cultural distance would tend to interact negatively with market size in determining the attractiveness of export markets. He did not consider geographic distance. His results appeared to show that psychic, but not cultural, distance makes large foreign markets less attractive for the initiation of sales. He observed that there was "no correlation between psychic distance and entry sequence" and further, that psychic distance moderated "the negative relationship between market size and entry sequence" (Ellis, 2008, 363). In other words, although large markets are in themselves more likely to attract sales of foreign products and services, when the psychic distance of that large market is high, the likelihood of attracting foreign sales is lower. One cannot be certain why psychic distance but not cultural distance would interact with foreign market size. However, in Ellis's study psychic distance was derived directly from the perceptions of exporters, while 
cultural distance came from a composite of Hofstede's (2001) various national values. We have already noted the weaknesses of such broad measures of cultural distance, and Ellis (2008) admitted similar concerns.

Despite Ellis's (2008) findings, we believe that his original theory may be correct. Indeed, some studies support and broaden his focus on the moderating effects of distance. Malhotra et al. (2009) focused not on exports but on cross-border acquisitions and studied not only China but eighteen developing countries. Although the researchers did not consider psychic distance, their analysis of interaction effects revealed significant moderation effects between cultural and geographic distance, the size of the market (measured as country GDP), and the number of cross-national-border acquisitions. They used a measure of culture that was similar to Ellis's (2008), but their use of marginal analysis to understand the interactions may have shown certain effects related to culture which could not be shown by Ellis's (2008) analysis. It should also be noted that Malhotra et al. (2009) and Ellis (2008) studied different foreign entry modes, and that this might explain some of the differences in their findings. A recent study by Brock et al. (2011) on the internationalization of small firms is consistent with Ellis (2008), in that it revealed that in foreign market entry psychic distance tends to negate the attractiveness of market size.

In addition to moderating the positive effect of market size on the attractiveness of foreign markets, cultural distance has an important direct effect on psychic distance (e.g. Dow and Karunaratna, 2006; Håkanson and Ambos, 2010). Widely held cultural beliefs greatly influence a culture's institutions and incentives for growth and change (North, 2005). Cultures influence what individuals and small groups believe, how they behave, how different they are from those in other cultures, and how they react to novelty (Hofstede, 2007). 
When small and new ventures attempt to sell innovative products in new foreign markets, the distance of the foreign culture from the home culture of the venture greatly influences whether individuals and groups in the foreign culture will be able to understand and accept the innovation (Alam, 2009; Child et al., 2009). Although some cultures are relatively more willing to permit adaptations by individuals, all cultures tend to reinforce the status quo. Individuals and organizations have routines, and the cultures in which they are embedded usually permit only incremental change in those routines (Johanson and Vahlne, 2009; North, 2005). Hence, for relatively short periods (possibly just a few years), cultures reinforce the effects of psychic distance and may well decrease the attractiveness of an otherwise large foreign market. This is especially critical for small and new ventures which, in many cases, are aiming to internationalize into leading markets for their niche product offering (Bell et al., 2003; Oviatt and McDougall, 1994). In view of this, we propose ${ }^{2}$ the following:

Proposition 1: For small and new ventures, the cultural distance to a foreign market will tend to accentuate the negative effect of psychic distance on the attractiveness of a large foreign market.

Compared to cultural and psychic distance, geographic distance is a unitary concept measured in miles, kilometers, or perhaps the time needed to cover those physical distances. Probably because it is unidimensional, its empirical effect on foreign entry and the initiation of foreign sales has been relatively clear, strong, and negative for MNCs (Clark and Pugh, 2001; Hutzschenreuter et al., 2014) and for small and new ventures (Dow, 2000; Gripsrud and Benito, 2005; Malhotra et al., 2009; Ojala and Tyrväinen, 2007; Ragozzino, 2009).

\footnotetext{
${ }^{2}$ Ceteris paribus conditions apply to all propositions. Propositions 1-2 and 6-7 are presented at the individual level, that is, with respect to decision makers within the organization to predict the behavior of a firm. Propositions 3-5 are presented at a national level, focusing on the aggregate behavior of firms. This division is in line with the work by Dow and Karunaratna (2006).
} 
By contrast, the effect of cultural distance is not empirically clear since (as noted above) it is sometimes difficult to distinguish the relevant group to which a measure applies, and further, there are many concepts and measures of culture (Avloniti and Filippaios, 2014; Shenkar, 2001). For example, Rothaermel et al. (2006) used Hofstede's national culture components to measure foreign market selection by US Internet firms. They found that uncertainty avoidance reduced the probability of a foreign market entry, while individualism and masculinity increased it.

If we assume that psychic distance (see Proposition 1) is reinforced by cultural distance, and further, that change in psychic distance is sometimes deliberate - especially in the case of small and new ventures (Ojala, 2008) - understanding the effect of psychic distance may be even more elusive than for cultural distance. In addition, an understanding of psychic distance is made more empirically difficult by the fact that it is asymmetrical for buyers and sellers, given that it is based on the perceptions of individuals (Ellis, 2008; Håkanson and Ambos, 2010; Sousa and Bradley, 2006).

In summary, because the concept and measures of geographic distance are unidimensional, with empirical studies on its effects giving relatively consistent results, and because cultural distance and psychic distance are more complex, we believe geographic distance has the more powerful moderating effect on the attractiveness of foreign market size. Research on the relationship between distance and the attractiveness of foreign markets is especially important for small and ventures which are not able to cope with distance dimensions to the same extent as MNCs (Oviatt and McDougall, 1994; Vachani, 2005). This leads to our second proposition:

Proposition 2: Especially for small and new ventures, the impact of distance on the attractiveness of foreign markets is weakened in the following diminishing degrees of magnitude: (i) geographic distance, (ii) cultural distance, (iii) psychic distance. 
It is important to test Proposition 2 because there is evidence that may contradict it. For example, some New Zealand small and new ventures have tended to enter the British market very early in their existence, and vice versa, despite the great geographical distance (Chetty and Campbell-Hunt, 2003). These have been termed "exceptions" in which psychic and cultural distance does not match geographic distance (Johanson and Wiedersheim-Paul, 1975). Such colonial exceptions may be based on historical events and migration patterns over long periods in ways that make geographic distance less salient as a moderator. However, the question then arises as to whether the exception is truly exceptional, based on atypical circumstances and merely "proving the rule," or whether it is genuine evidence that Proposition 2 does not hold in the larger global arena.

Propositions 1 and 2 are depicted in Figure 2 below. The relative sizes of the distance boxes reflect the proposed progressively diminishing strengths of the three dimensions of distances as mediators of the positive impact of foreign market size on the attractiveness of the foreign market. In addition, Figure 2 also shows how cultural distance augments the negative effect of psychic distance on the attractiveness of a large foreign market. The authors know of no prior study that considers the relative power of these different manifestations of distance, in terms of their influence on the initiation of foreign sales by new and small ventures.

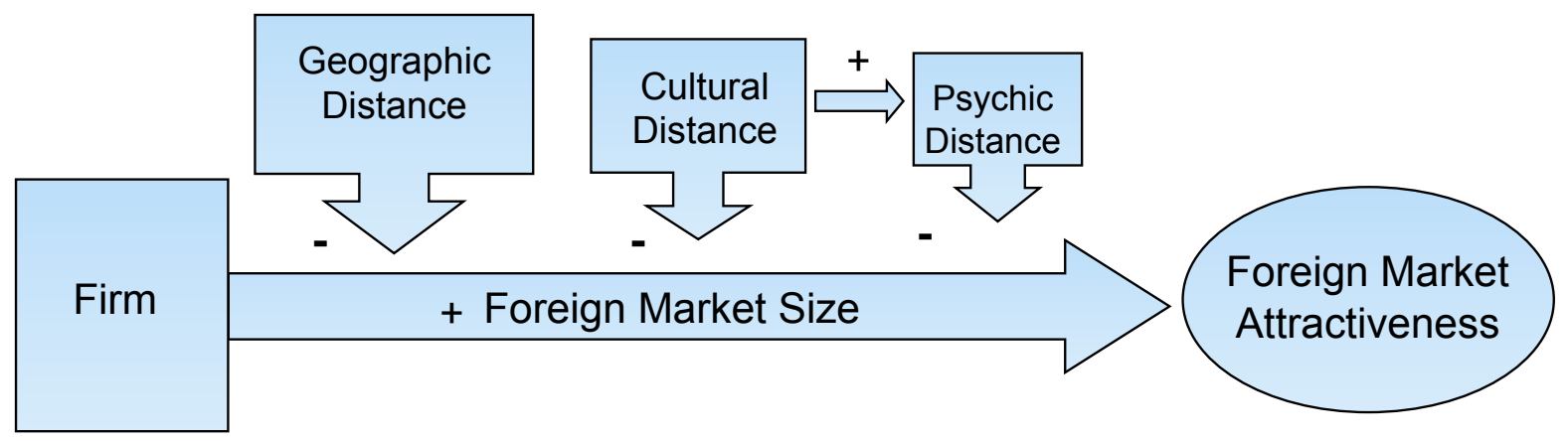

Figure 2. Distance dimensions, foreign market size, and foreign market attractiveness 


\section{The Stability of Distance}

Over time, distance dimensions change. Geographic distance is the most stable of the three dimensions of distance because it is concerned with the space between constant positions on the surface of the Earth. However, the perception of geographic distance does slowly change (Puthusserry et al., 2014). Modern air transport and communications have reduced the experienced and perceived physical distance between home and foreign locations, and have eased commercial interaction. Child et al. (2002) refer to these as "distance-compressing factors."

Such factors also affect change in cultural distance (Child et al., 2002). Cultural beliefs determine the kinds of institutions present in a society, and, in turn, those institutions establish incentives for change and growth (North, 2005). Some scholars have observed environmental and technological changes which, when combined with competitive incentives, tend to cause a degree of international homogenization in life-styles, business practices, and national institutions (Child et al., 2002; North, 2005). Thus, international cultural distances appear to be decreasing. For example, some age groups in ancient Asian cultures are now influenced (at least much more than before) by Western habits, commercial norms, and changing fashion. Such distance compression has made foreign markets less culturally distinct over time and, therefore, easier to enter by small and new ventures from other countries (Autio, 2005). Despite this, Hofstede (2007) emphasizes that although cultures change, they do not homogenize. He concedes that similar commercial behaviors are apparent across countries, and that some Asian nations are becoming less collectivist and more "Western" in their individualistic cultural orientation. However, he maintains that basic cultural beliefs and values continue to distinguish one culture - including its management style - from another, and that such distinctions will never be erased. 
Whether the increasing similarities or the continuing distinctions are emphasized, there is general agreement that cultural change is incremental, evolutionary, and greatly dependent on the path that has previously been followed (Child et al., 2002; Hofstede, 2007; North, 2005; Stoelhorst, 2008). Modern communication permits the international dissemination of business practices, the arts, entertainment, fashion, and numerous other factors that may compress cultural distance. One frequently mentioned distance-compressing factor is scientific knowledge, which disseminates around the world; however, the cultural changes it brings may be either facilitated or constrained by religion, education, politics, and the degree of economic development (North, 2005).

Because so many issues can contribute to cultural change, it seems obvious that cultural distance is less stable over time than geographic distance. However, with increasingly rapid transportation and information flow, new and small ventures may be able to overcome some of the main obstacles created by geographic distance (Arenius et al., 2005; Loane, 2006). Furthermore, perceptions of geographical distance may vary among individual managers (Puthusserry et al., 2014). This makes the impact of geographic distance uncertain.

All in all, there are contradictory arguments related to the stability of cultural and geographic distance. As far as we know, the stability between geographic and cultural distance has never been empirically tested. We believe that in research on the consistency of small and new ventures the stability of the dimensions should not be overlooked, given that both dimensions clearly impact on foreign market entry (Dow, 2000; Ojala and Tyrväinen, 2007, 2008; Puthusserry et al., 2014). Establishing which distance dimensions are more or less stable will improve our understanding of the most salient influences on the decisions by small and new ventures to initiate foreign sales. We thus believe that it is important to test the following proposition: 
Proposition 3: The geographic distance to foreign markets is more stable than the cultural distance to foreign markets.

Changes in culture and cultural distance may broadly affect most people in a country, or they may be particular to a single group of people in a country (or multiple countries). Most of the examples of changes in cultural distance highlighted above are broad-based, and many result from changes which improve or hasten communication over many countries, and which reduce the costs of transportation. Under such circumstances, people from various cultures will tend to interact more, and may start to share more beliefs.

Despite this, most countries have important groups of people with cultural beliefs and behaviors that are distinct from but tolerated or even welcomed by the country's mainstream. The norms of some relatively isolated groups, such as Native Americans on reservations, may be changed only very slowly by the wider national culture. Asian firms in particular have been able to utilize emigrant relationships in Europe and the United States - and also returning migration relationships - to help them initiate sales in distant locations, even where the dominant national cultures are quite different from their own (Bagwell, 2008; Child et al., 2002; Prashantham and Dhanaraj, 2010). A diaspora from any country may create influential sub-cultures in countries where minorities share similar values and behaviors (Alden et al., 1999; Hannerz, 1990). Business growth opportunities exist across countries with such diversity.

The presence of cultural diversity in a country means that changes in a country's cultures can be as varied as its number of sub-cultures. As a consequence, changes in cultural distance between countries may also be quite varied, and as the population of a sub-culture within a country increases, its influence on the wider population may also increase. For example, the migration of Turks into Western Europe over many decades (Martin, 1991) has reduced the cultural distance to Germany for many small Turkish businesses. In such 
circumstances it seems appropriate to study the pluralism of cultural distances between countries and the changes that may occur in this domain. This is an issue that is often ignored in empirical studies on cultural distance (Shenkar, 2001). Moreover, the issue is more widespread than is usually recognized. Some global industries, such as the computer industry, have emerged with their own worldwide diaspora of a common language or languages, plus shared beliefs and norms, despite the existence of differing national backgrounds among industry players (Andersson, 2004; Hannerz, 1990). Science- and engineering-based industries, whose beliefs about cause, effect, and values are embedded in the physical sciences, would appear to be especially prone to international sub-culture formation. Such industries are precisely those that most frequently offer opportunities to small and new ventures for the initiation of international sales (Oviatt and McDougall, 1999). Thus, subcultural distance compression can emerge in many circumstances when sub-cultures are international, leading to the following proposition:

Proposition 4: Both the variety and the stability of cultural distances to foreign markets are determined by the number of sub-cultures in a country. Multiple subcultures yield multiple distances with varying stabilities in relation to cultures in other countries.

Child et al. (2002) highlight alterations in psychic distance that are brought about by the initiatives of firms and individuals. These involve what they refer to as "distance-bridging factors." An example would be the employment of trusted colleagues or family members to ensure that organizational operations in foreign locations are consistent with home-country expectations (Child et al., 2002). Because such actions are deliberate and perhaps even sudden, some changes in psychic distance may be more rapid than changes in cultural distance in their effect on the international expansion of small and new ventures (Child et al., 
2009; Ojala, 2008). For the same reason, changes in psychic distance may seem idiosyncratic and difficult to understand for observers. Thus we arrive at the following proposition:

Proposition 5: The psychic distance to foreign markets is relatively variable compared to cultural and geographic distance, due to the fact that its change may be deliberate and may affect a relatively small group of people.

The degree of stability among the three dimensions of distance is depicted in Figure 3. The preceding propositions $(3,4$, and 5$)$ indicate that the passage of time is likely to have varying effects on different dimensions of distance between markets in various countries. If the logic in the prior paragraphs and propositions is supported, it becomes clear that time is another factor that must be considered when researchers explore the effects of distance on the initiation of foreign sales by small and new ventures.

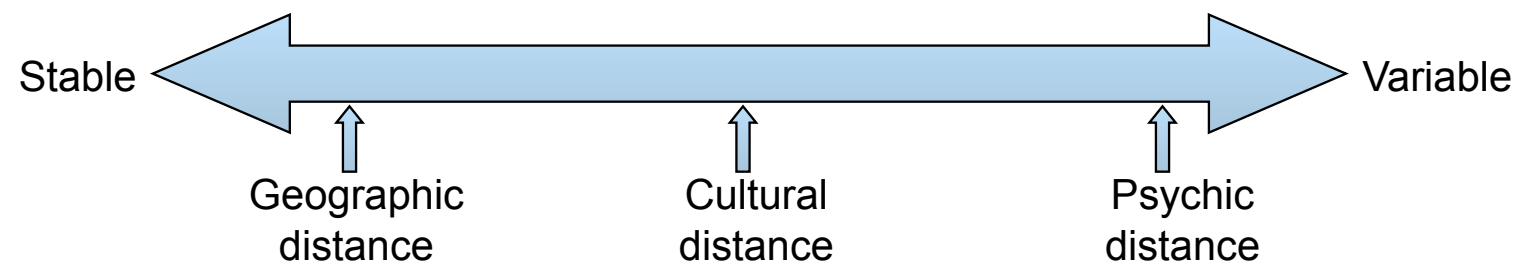

Figure 3. Types of distance and their stability

\section{The Interactive Role of Network Relationships}

Some of the scholars who gave us the Uppsala Model have explored network models of internationalization (Johanson and Mattsson, 1988; Johanson and Vahlne, 2003). Recently, they have revised their concepts to form a business network model of internationalization (Johanson and Vahlne, 2009). They view current business practices as so immersed in webs of international networks that independent entries by firms into foreign markets are largely 
discounted in the model. Indeed, the most salient factor in a firm's internationalization is its membership of a network, which is often established by linkages between individuals. Thus, it appears that networks primarily influence psychic distance, but that choosing the right network - more than psychic distance between markets - may be the prime source of firm uncertainty when moving towards internationalization. In weighing up such considerations, Johanson and Vahlne (2009) see an important empirical question arising as to whether the problems of distance between markets in different countries may be overcome by business network relationships.

Several studies (Agndal et al., 2008; Coviello, 2006; Coviello and Martin, 1999; Yu et al., 2011) have focused on the personal and business networks of new and small ventures, and have indicated that networks play an important role in their internationalization. Such networks may reduce or "bridge" psychic distance (Child et al., 2002; Coviello and Martin, 1999; Ojala, 2009), overcoming fairly stable cultural distances. In this way they help small and new venture managers to enter countries in which geographic distance is great and constant (Johanson and Vahlne, 2009). One can see how network formation for small and new ventures may be demanding, in so far as they are more susceptible to the liability of foreignness than large firms (Lu and Beamish, 2001). In line with this, Johanson and Vahlne (2009) argue that great psychic distance makes it more difficult to build new network relationships in otherwise attractive foreign markets. Nevertheless, although some empirical studies (Lu and Beamish, 2001; Kontinen and Ojala, 2010) have indicated that psychic distance may increase the time and resources needed for network formation, the relationship between the factors in question remains unclear: some studies have indicated that networks make market entry possible even in very distant markets (Ojala, 2009), while others suggest that the network formation of small and new ventures is not in fact related to psychic distance (Oviatt and McDougall, 1994, 2005). Despite this, it seems reasonable to assume that, other 
things being equal, psychic distance at the very least complicates the process of building trust and commitment among potential foreign partners, and will tend to increase the time and resources needed to become an insider in a foreign network. Thus:

Proposition 6: In attempting to enter foreign markets, small and new ventures will tend to use network relationships for the purpose of bridging psychic distance, more than for the purpose of bridging geographic or cultural distance.

Proposition 7: The greater the psychic distance to a foreign market, the more the time and resources required from small and new ventures to build, or to find and develop, a network that will bridge that distance.

\section{Suggestions regarding the measurement of different dimensions}

In this section we shall put forward some suggestions concerning how to measure the different dimensions referred to in the propositions developed above. Space limitations do not permit us to fully explore designs for testing the variety of propositions, but some approaches are suggested below. In addition, the empirical testing of the propositions is highly dependent on the context of the study, given that firms from different industries may experience distance in different ways (e.g. Puthusserry et al., 2014). For this reason, we shall highlight some important considerations regarding the variables to consider in future studies.

\subsection{Measurement of foreign sales and foreign market size}

The measurement of foreign sales is straightforward. When a venture begins to sell its outputs in a country beyond its home country, an event to be explained has occurred. Researchers may wish to determine the strength of the initiation by measuring the percentage of total firm sales represented by the initial foreign sales, how rapidly those foreign sales 
have grown over time, or how many foreign countries or cultures have been entered within some short period, such as a year.

The measurement of market size can be a challenge as there are different indicators to evaluate the actual market size, and moreover, the size of the market may change over time. Some scholars have used the size of a country's economy, such as gross domestic product (GDP) (Brock et al., 2011; Ellis, 2008; Luostarinen, 1989; Terpstra and Yu, 1988) or gross domestic product per capita (GDP per capita) (Clark and Pugh, 2001; Rothaermel et al., 2006) when investigating the impact of market size. In the case of small and new ventures, we believe that the definition of market size should be based on the vertical market (Ojala and Tyrväinen, 2007, 2008), that is, the potential sales of all products of interest in a particular geographic location. For example, if a firm is developing software for the oil industry, the market size depends on the size of the oil industry in the location where the firm wants to sell its software (see Bell, 1995). In these cases, usage of merely GDP or GDP per capita as an indicator of market size might lead to misleading results. Note that vertical markets size works best if a study includes only a single industry; in the case of multiindustry studies usage of vertical market size will become more complex. The market size of the target country may also vary between the time of the entry and the year of the investigation. For this reason, it is important to use the actual market size in the year of a firm's market entry (see e.g. Ellis, 2008) to increase the reliability of the findings.

\subsection{Measures of Distance}

Geographic distance. Geographic distance is the space separating the location of each seller from that of each buyer. The closer researchers can come to that concept, the greater precision their studies will have. The distance between capital cities (Brock et al., 2011; 
Clark and Pugh, 2001; Luostarinen, 1989; Terpstra and Yu, 1988), major cities (Hutzschenreuter et al., 2014; Håkanson and Ambos, 2010), seaports (Ellis, 2007), and the geographic centers of countries (Ojala and Tyrväinen, 2007, 2008) have been employed with success. In addition to these objective, national-level measures, Puthusserry et al. (2014) applied a subjective, individual-level measure of geographic distance when they studied the perceptions of managers regarding spatial distance from their firms. This means that the selection of the correct indicator for geographic distance will depend on the level of analysis (individual or firm) and the characteristics of the product or service. For instance, in the case of physical products, seaports might provide the best measure, whereas in the case of immaterial products, such software, geographic centers of countries are more useful - in the latter case because the location of customers within the country can be difficult to evaluate, and because there are no logistical issues to consider. Overall, objective, national-level analyses are useful when one is seeking to know how firms behave in general. However, subjective, individual-level analyses are applicable in situations when researchers are interested in how managers or employees conceptualize or cope with geographical distance.

Cultural distance. Researchers have applied different scales to measure cultural distance. The most commonly used scales have been Hofstede's $(1980,2001)$ cultural dimensions, used together with the Kogut and Singh's (1988) composite index (e.g. Brock et al., 2011; Clark and Pugh, 2001; Dow, 2000; Ellis, 2007; Ojala and Tyrväinen, 2007, 2008), or with each of the dimensions applied independently (Dow and Karunaratna, 2006; Rothaermel et al., 2006). Other studies have applied Schwartz's (1999) framework together with Hofstede's dimensions (e.g. Brock et al., 2011; Drogendijk and Slangen, 2006) and/or the GLOBE framework (House et al., 1999) to evaluate cultural differences (e.g. Avloniti and Filippaios, 2014; Malhotra et al., 2011). It is possible to identify three different aspects of cultural 
distance that empirical researchers must consider and match to the theory they are using: (1) the particular cultural issues studied, (2) the societal groups under observation, and (3) the effect of time on the study. When scholars examine the effect of differences in communication patterns on the initiation of foreign sales, Hall and Hall's (1990) communication dimensions are appropriate. However, when (for example) differences in power distance or time orientation between societies become salient, researchers should consider explanatory measures such as Hofstede's (2001) cultural dimensions. As noted above, we believe the potential for "cultural friction" occurs when some aspect of cultural distance causes conflict between an organization and its host culture. Research on the issue will be facilitated by a direct measure of the degree of friction (Luo and Shenkar, 2011). In our view scholars must move away from collective measures of multiple cultural dimensions, and instead develop theory concerning the specific effects of a culture on the initiation of foreign sales (see e.g. Dow and Karunaratna, 2006; Rothaermel et al., 2006). In addition, scholars should avoid grouping everyone in a country within a single society, bearing in mind the problems that can occur in national-level analyses. When studying the initiation of foreign sales in a single industry, the theoretically appropriate cultural dimension in that industry will be the appropriate focus, not aspects pertaining to the entire population living in the country. Here one has to bear in mind that some industries are more global than others, including for example, the telecommunications industry with its worldwide standards. In these cases, differing national backgrounds among industry players might have a lower impact compared to other, more local industries. These are important factors to consider when studying and measuring cultural distance.

When a study is longitudinal, a cultural dimension within a societal group in a foreign country may change during the time period of the research. Advanced communication technologies and social media, for example, may enable individuals to participate in new sub- 
cultures and cause sub-cultures to change in the course of the study (Williams, 2006). Thus, scholars must be sensitive to the possibility of cultural distance compression and its effect on the decisions of venture entrepreneurs. As we have emphasized, advances in this research domain require that the measure of cultural distance should be specific and should have theoretical interest. Along these lines, Rothaermel et al. (2006) developed theory on how uncertainty avoidance, individualism, masculinity, and power distance would affect foreign entry by U.S. Internet companies. Their results showed support for most of their hypotheses.

Psychic distance. Measurement of psychic distance has been complex, and it is only recently that researchers have developed scales that can be applied to measure psychic distance. Most studies so far have evaluated psychic distance by asking managers to rank countries from the most familiar to the most distant (e.g., Brock et al., 2011; Dow, 2000; Ellis, 2008; Håkanson and Ambos, 2010; Nordström, 1991), or by asking managers to evaluate the differences between the home and the target country (e.g., Child et al., 2009; Puthusserry et al., 2014; Sousa and Lages, 2011). In addition to these individual-level measurements, some scholars have developed scales that can be applied to measure psychic distance at national level (Brewer, 2007; Dow and Karunaratna, 2006). More recently, the psychic distance stimuli scales devised by Dow and Karunaratna (2006) have been applied in several studies (see e.g. Avloniti and Filippaios, 2014; Dow and Ferencikova, 2010; Dow and Larimo, 2011; Drogendijk and Martin, 2015).

On the basis of the literature, there are three aspects of psychic distance that researchers must consider: (1) specific measures, distinguished from measures of cultural distance, (2) the effect of time on the study, and (3) the context of the study. Ellis (2008) provides one example of how specific measures might be achieved. He asked a sub-sample of managers in the firms he was studying to rate the perceived distances of countries to which 
they were exporting. Here is should be borne in mind that foreign sales may be initiated from either the buyer or the seller; hence, researchers must be careful to measure psychic distance from the perspective of the initiator. While the precise initiator may not always be clear, studies such as those of Coviello and Munro (1995) and Ojala (2009) have shown that the initiator can indeed be identified.

Psychic distance changes over time. Because changes in psychic distance may be relatively rapid - and even deliberate - when data collection extends over a lengthy period, researchers should ensure that the perceptions of subjects do not change over that time, or if they do change, the researchers should measure the change as an additional variable. The context of the study is also important. Especially in the case of small and new ventures, there have been mixed results concerning the impact of psychic distance on small and new ventures (Brock et al., 2011). It also seems that some industries are more sensitive to the impact of psychic distance than others (Bell et al., 2001).

At the individual level, psychic distance refers to the perceptions of individuals which influence small groups or organizations. In the early development of studies on this aspect, qualitative methods are most appropriate, making it possible to consider also the impact of time, and the asymmetrical nature of psychic distance (Edmondson and McManus, 2007). Although this approach decreases the generalization of the findings, it facilitates the kind of in-depth knowledge that can be later tested via quantitative methods. At the national level, when researchers are more interested in the aggregate behavior of firms, the psychic distance stimuli scale by Dow and Karunaratna (2006) can be applied. However, researchers should be aware that, in quantitative studies, the initiator of foreign sales may be difficult to recognize. Furthermore, researchers should acknowledge that psychic distance stimuli may vary considerably between different industries and at different points of time within the study. 
Measures of the impact of networks. Although a variety of network measures may describe external firm alliances and linkages (Burt, 1992) and may be of interest to scholars in explaining the initiation of foreign sales, the propositions in this paper require (1) the existence of formal business ties or informal personal ties to be recognized, along with (2) knowledge of which actors within the network are active in selecting foreign countries. Proposition 6 (that networks bridge psychic distance), and Proposition 7 (that greater psychic distance requires more resources and time for successful bridging) are less well developed in terms of theory and empirical examination than the other propositions. Thus, qualitative case studies may be required to explore them and to develop appropriate constructs (Edmondson and McManus, 2007). If qualitative case studies are undertaken, the key decision makers involved in network formation can be interviewed (Coviello, 2006; Coviello and Munro, 1997; Coviello and Martin, 1999; Ojala, 2009) and researchers can form an in-depth understanding of (1) how the actions taken by the decision maker helped to overcome the psychic distance, (2) what resources were needed, and (3) how much time was required. Working along these lines, Ojala (2009) took some of these factors into account by asking managers to describe important events, persons, firms, or organizations that had influenced their foreign market entry.

\section{Conclusions}

This conceptual study contributes to international business literature in several ways. First of all, it develops an understanding of (1) how the main distance dimensions operate as mediators which progressively diminish the positive impact of foreign market size on the attractiveness of a foreign market, and (2) how cultural distance increases the negative effect of psychic distance on the attractiveness of a large foreign market. This is especially 
important for small and new ventures, which are aiming at large markets, but which have limited resources or international experience (Bell et al., 2003; Oviatt and McDougall, 1994).

Secondly, this study contributes to conceptualizations of the stability of the three distance dimensions. In this respect, the study has links with the argument by Shenkar (2001) concerning the "illusion of stability." It clarifies how geographical distance is likely to be the most stable dimension, followed by cultural distance and psychic distance. These are important factors to consider when one is conducting research on distance dimensions, given that changes in these dimensions may impact considerably on the findings of a study. In addition, the stability of these factors should not be overlooked in the case of small and new ventures, since the factors may all impact significantly on the international expansion of such firms (Brock et al., 2011; Dow, 2000; Ojala and Tyrväinen, 2007, 2008; Puthusserry et al., 2014).

Thirdly, this study shows how network relationships may help small and new ventures to bridge distance dimensions, especially psychic distance. This is important for small and new ventures, as their main resources are commonly tied to the resources that are available only through their network relationships (Coviello, 2006; Oviatt and McDougall, 1994, 2005). However, up to now, the literature on psychic distance and on network relationships has not considered the interplay between these factors in any depth; indeed, one could say that it is only recently that this aspect has begun to receive the attention it deserves - both in general (Johanson and Vahlne, 2009) and in the context of small and new ventures (Child et al., 2009; Ojala, 2009; Puthusserry et al., 2014).

Finally, this study discusses the measurement of market size, different distance dimensions, and the impact of network relationships. It also suggests some important considerations when scholars use these dimensions or test the propositions developed in this study. Despite criticisms (e.g. Håkanson and Ambos, 2010; Shenkar, 2001), scholars have 
continued to use a variety of distance dimensions as explanatory variables for foreign entry, international sales, and other issues, while giving insufficient attention to the qualities of the dimensions themselves (Håkanson and Ambos, 2010). The results have been particularly mixed with regard to the impact of distance dimensions on small and new ventures (Brock et al., 2011). We hope that a better understanding of these dimensions and of their interactive role may help to clarify further studies on distance in the context of small and new ventures.

We acknowledge that some of the relationships indicated in the propositions are likely to be very complex, and that the possibilities for generalizing the results from any given study may be limited. In addition, the influence of some of the variables in the framework may vary depending on the country of origin and the industry involved. Thus, for example, in the case of Russian small and new ventures, difficulties with certain distance factors have emerged that are not that visible for Western firms (Bruton and Rubanik, 2002; Tovstiga et al., 2004). One also has to bear in mind that the context of a study, involving for example the industry and the type of product/service, may have an interactive role with distance dimensions. Thus, to take an example, Internet firms may be able to overcome some important distance-creating factors (Arenius et al., 2005; Loane, 2006). Furthermore, highly standardized products and services may be easier to sell to distant markets than customized products and services. These are all important issues that will merit further investigation.

\section{Acknowledgments}

The author would like to thank Benjamin Oviatt for his great cooperation with the earlier version of this paper presented at the $13^{\text {th }}$ McGill International Entrepreneurship Conference. In addition, the author is thankful for Pasi Tyrväinen and the anonymous reviewers for their valuable comments and suggestions. The research has been generously funded by the Emil 
Aaltonen Foundation and Foundation for Economic Education.

\section{References}

Agndal, H., Chetty, S, Wilson, H., 2008. Social capital dynamics and foreign market entry. International Business Review 17 (6), 663-675.

Alam, S.S. 2009. Adoption of internet in Malaysian SMEs. Journal of Small Business and Enterprise Development 16 (2), 240-255.

Alden, D.L., Steenkamp, J-B.E.M., Batra, R., 1999. Brand Positioning Through Advertising in Asia, North America, and Europe: The Role of Global Consumer Culture. Journal of Marketing 63 (1), 75-87.

Ambos, B., Håkanson, L. 2014. The Concept of Distance in International Management Research. Journal of International Management 20 (1), 1-7.

Andersson, S. 2004. Internationalization in different industrial contexts. Journal of Business Venturing $19(6), 851-875$.

Arenius, P., Sasi, V., Gabrielsson, M. 2005. Rapid internationalisation enabled by the Internet: The case of a knowledge intensive company. Journal of International Entrepreneurship 3 (4), 279-290.

Autio, E. 2005. Creative tension: the significance of Ben Oviatt's and Patricia McDougall's article 'toward a theory of international new ventures'. Journal of International Business Studies $36(1), 9-19$.

Autio, E., Sapienza, H.J., Almeida, J.G. 2000. Effects of age at entry, knowledge intensity, and imitability on international growth. Academy of Management Journal 43 (5), 909924. 
Avloniti, A., Filippaios, F. 2014. Unbundling the differences between Psychic and Cultural

Distance: An empirical examination of the existing measures. International Business Review 23 (3), 660-674.

Bagwell, S. 2008. Transnational family networks and ethnic minority business development:

The case of Vietnamese nail-shops in the UK. International Journal of Entrepreneurial Behaviour \& Research 14 (6), 377-394.

Bartlett, C., Ghoshal, S., Beamish, P., 2008. Transnational Management, $5^{\text {th }}$ Edition, McGraw Hill: Boston.

Bell, J. 1995. The Internationalization of Small Computer Software Firms: A Further Challenge to "Stage" Theories. European Journal of Marketing 29 (8), 60-75.

Bell, J., McNaughton, R., Young, S. 2001. 'Born-again global' firms: An extension to the 'born global' phenomenon. Journal of International Management 7 (3), 173-189.

Bell, J., McNaughton, R., Young, S., Crick, D. 2003. Towards an integrative model of small firm internationalization. Journal of International Entrepreneurship 1 (4), 339-362.

Beckerman, W. 1956. Distance and the pattern of intra-European trade. The Review of Economics and Statistics 38 (1), 31-40.

Blum, B.S., Goldfarb, A., 2006. Does the Internet defy the law of gravity? Journal of International Economics 70 (2), 384-405.

Boehe, D.M. 2009. Brazilian Software SME’s Export Propensity: Bridging "Born Global" and Stage Approaches. Latin American Business Review 10 (2-3), 187-216.

Brewer, P. 2007. Operationalizing Psychic Distance: A Revised Approach. Journal of International Marketing 15 (1), 44-66.

Brock, J.K-U., Johnson, J.E., Zhou, J.Y., 2011. Does distance matter for internationallyoriented small firms? Industrial Marketing Management 40 (3), 384-394. 
Bruton, G.D., Rubanik, Y. 2002. Resources of the firm, Russian high-technology startups, and firm growth. Journal of Business Venturing 17 (6), 553-576.

Burt, R.S. 1992. Structural Holes, Harvard University Press, Cambridge.

Chetty, S., Campbell-Hunt, C., 2003. Paths to internationalisation among small-to mediumsized firms. European Journal of Marketing 37 (5-6), 796-820.

Child, J., Ng, S.H., Wong, C., 2002. Psychic distance and internationalization: Evidence from Hong Kong Firms. International Studies of Management and Organizations 32 (1), 36-56.

Child, J., Rodrigues, S.B., Frynas, J.G., 2009. Psychic Distance, its Impact and Coping Modes: Interpretations of SME Decision Makers. Management International Review 49, 199-224.

Clark, T., Pugh, D.S., 2001. Foreign country priorities in the internationalization process: a measure and an exploratory test on British firms. International Business Review 10 (3), 285-303.

Coviello, N. 2006. The network dynamics of international new ventures. Journal of International Business Studies 37 (5), 713-731.

Coviello, N.E., Martin, K.A-M., 1999. Internationalization of Service SMEs: An Integrated Perspective from the Engineering Consulting Sector. Journal of International Marketing 7 (4), 42-66.

Coviello, N., Munro, H., 1995. Growing the entrepreneurial firm: Networking for international market development. European Journal of Marketing 29 (7), 49-61.

Coviello, N., Munro, H., 1997. Network Relationships and the Internationalisation Process of Small Software Firms. International Business Review 6 (4), 361-386.

Dow, D. 2000. A Note on Psychological Distance and Export Market Selection. Journal of International Marketing 8 (1), 51-64. 
Dow, D. 2005. Do Born Global Firms Represent a Truly Distinct Type of Organisation? Paper presented at Academy of International Business Conference, Quebec, Canada, June 2005.

Dow, D., Ferencikova, s., 2010. More than just national cultural distance: Testing new distance scales on FDI in Slovakia. International Business Review 19 (1), 46-58.

Dow, D., Karunaratna, A., 2006. Developing a multidimensional instrument to measure psychic distance stimuli. Journal of International Business Studies 37 (5), 578-602.

Dow, D., Larimo, J. 2011. Disentangling the Roles of International Experience and Distance in Establishment Mode Choice. Management International Review 51 (3), 321-355.

Drogendijk, R., Martin, M.O. 2015. Relevant dimensions and contextual weights of distance in international business decisions: Evidence from Spanish and Chinese outward FDI. International Business Review 24 (1), 133-147.

Drogendijk, R., Slangen, A. 2006. Hofstede, Schwartz, or managerial perceptions? The effects of different cultural distance measures on establishment mode choices by multinational enterprises. International Business Review 15 (4), 361-380.

Dunning, J.H. 2001. The eclectic (OLI) paradigm of international production: past, present, and future. International Journal of the Economics of Business 8 (2), 173-190.

Edmondson, A.C., McManus, S.E., 2007. Methodological fit in management field research. Academy of Management Review 32 (4), 1155-1179.

Ellis, P. 2007. Paths to foreign markets: Does distance to market affect firm internationalization? International Business Review 16 (5), 573-593.

Ellis, P. 2008. Does psychic distance moderate the market size-entry sequence relationship? Journal of International Business Studies 39 (3), 351-369. 
Estrin, S., Baghdasaryan, D., Meyer, K.E., 2009. The Impact of Institutional and Human Resource Distance on International Entry Strategies. Journal of Management Studies 46 (7), 1171-1196.

Freeman, S., Giroud, A., Kalfadellis, P., Ghauri, P. 2012. Psychic distance and environment: impact on increased resource commitment. European Business Review 24 (4), 351-373.

Gannon, M.J. 1994. Understanding Global Cultures. Sage: CA.

Ghemawat, P. 2001. Distance Still Matters: The Hard Reality of Global Expansion. Harvard Business Review 79 (8), 137-147.

Gooris, J., Peeters, C. 2014. Home-Host Country Distance in Offshore Governance Choices. Journal of International Management 20 (1), 73-86.

Gripsrud, G., Benito, G.R.G., 2005. Internationalization in retailing: modeling the pattern of foreign market entry. Journal of Business Research 58 (12), 1672-1680.

Hall, E.T., Hall, M.R., 1990. Hidden Differences: Doing Business with the Japanese, Anchor, New York.

Hannerz, U. 1990. Cosmopolitans and locals in world culture, in Featherstone, M. (Ed.), Global Culture: Nationalism, Globalization and Modernity, pp. 237-251, Sage, CA.

Hashai, N., Almor, T., 2004. Gradually internationalizing 'born global' firms: an oxymoron? International Business Review 13 (4), 465-483.

Hitt, M.A., Bierman, L., Uhlenbruck, K., Shimizu, K., 2006. The importance of resources in the internationalization of professional service firms: the good, the bad, and the ugly. Academy of Management Journal 49 (6), 1137-1157.

Hebdige, D. 1979. Subculture: The meaning of style. Methuen, London.

Hofstede, G. 1980. Culture's consequences, Sage, CA.

Hofstede, G. 2001. Culture’s Consequences, Second edition. Sage, NY. 
Hofstede, G. 2007. Asian management in the 21st century. Asia Pacific Journal of Management 24 (4), 411-420.

House, R.J. et al. 1999. Cultural influences on leadership and organization: Project GLOBE, in Mobley, W.H. Gessner, M.J. and Arnold, V. (Eds.), Advantages in global leadership, pp. 171-233, JAI Press, Stamford.

Hutzschenreuter, T., Kleindienst, I., Lange, S. 2014. Added Psychic Distance Stimuli and MNE Performance: Performance Effects of Added Cultural, Governance, Geographic, and Economic Distance in MNEs' International Expansion. Journal of International Management 20 (1), 38-54.

Håkanson, L., Ambos, B. 2010. The antecedents of psychic distance. Journal of International Management 16 (3), 195-210.

Johanson, J., Mattsson, L-G., 1988. Internationalisation in Industrial Systems - A Network Approach, in Hood, N. and Vahlne, J-E. (Eds.), Strategies in Global Competition, pp. 287-314, Croom Helm, London.

Johanson, J., Vahlne, J-E., 2003. Business Relationship Learning and Commitment in the Internationalization process. Journal of International Entrepreneurship 1 (1), 83-101.

Johanson, J., Vahlne, J-E., 2009. The Uppsala internationalization process model revisited: From liability of foreignness to liability of outsidership. Journal of International Business Studies 40 (9), 1411-1431.

Johanson, J., Wiedersheim-Paul, F., 1975. The internationalization of the firm: Four Swedish cases. Journal of Management Studies 12 (3), 305-322.

Kogut, B., Singh, H. 1988. The Effect of National Culture on the Choice of Entry Mode. Journal of International Business Studies 19 (3), 411-432.

Kontinen, T. 2011. Succeeding in the French market: recommendations for small businesses. Journal of Business Strategy 32 (1), 15-25. 
Kontinen, T., Ojala, A., 2010. Internationalization pathways of family SMEs: psychic distance as a focal point. Journal of Small Business and Enterprise Development 17 (3), 437-454.

Kreiser, P.M., Dickson, P., Weaver, K.M. 2010. Cultural Influences on Entrepreneurial Orientation: The Impact of National Culture on Risk Taking and Proactiveness in SMEs. Entrepreneurship Theory and Practice 34 (5), 959-983.

Leamer, E.E., Storper, M., 2001. The Economic Geography of the Internet Age. Journal of International Business Studies 32 (4), 641-665.

Leung, K., Bhagat, R.S, Buchan, N.r., Erez, M., Gibson, C.B. 2005. Culture and international business: recent advances and their implications for future research. Journal of International Business Studies, 36 (4), 357-378.

Loane, S. 2006. The role of the internet in the internationalisation of small and medium sized companies. Journal of International Entrepreneurship 3 (4), 263-277.

Lu, J.W., Beamish, P.W. 2001. The internationalization and performance of SMEs. Strategic Management Journal 22 (6-7), 565-586.

Luo, Y., Shenkar, O. 2011. Toward a perspective of cultural friction in international business. Journal of International Management 17 (1), 1-14.

Luostarinen, R. 1989. Internationalization of the Firm. Doctoral dissertation, Helsinki School of Economics, 3rd edition.

Malhotra, S., Sivakumar, K., Zhu, P., 2009. Distance factors and target market selection: the moderating effect of market potential. International Marketing Review 26 (6), 651-673.

Malhotra, S., Sivakumar, K., Zhu, P., 2011. Curvilinear relationship between cultural distance and equity participation: An empirical analysis of cross-border acquisitions. Journal of International Management 17 (4), 316-332. 
Martin, P.L. 1991. The unfinished story: Turkish labour migration to Western Europe: with special reference to the Federal Republic of Germany, ILO, Geneva.

Mezias, S.J., Chen, Y-R., Murphy, P. Biaggio, A., Chuawanlee, W., Hui, H., Okumura, T., Starr, S. 2002. National cultural distance as liability of foreignness: the issue of level of analysis. Journal of International Management 8 (4), 407-421.

Nebus, J., Chai, K.H. 2014. Putting the "psychic" Back in Psychic Distance: Awareness, Perceptions, and Understanding as Dimensions of Psychic Distance. Journal of International Management 20 (1), 8-24.

Nordström, K.A. 1991. The internationalization process of the firm: searching for new patterns and explanations. Doctoral Thesis. Stockholm School of Economics.

North, D.C. 2005. Institutions and the Process of Economic Change. Management International $9(3), 1-7$.

Ojala, A. 2008. Entry in a Psychically Distant Market: Finnish Small and Medium-sized Software Firms in Japan. European Management Journal 26 (2), 135-144.

Ojala, A. 2009. Internationalization of knowledge-intensive SMEs: The role of network relationships in the entry to a psychically distant market. International Business Review $18(1), 50-59$.

Ojala, A., Tyrväinen, P., 2007. Market entry and priority of small and medium-sized enterprises in the software industry: An empirical analysis of cultural distance, geographical distance, and market size. Journal of International Marketing 15 (3), 123 149.

Ojala, A., Tyrväinen, P., 2008. Market entry decisions of US small and medium-sized software firms. Management Decision 46 (2), 187-200.

Oviatt, B., McDougall, P., 1994. Toward a theory of international new ventures. Journal of International Business Studies 25 (1), 45-64. 
Oviatt, B., McDougall, P., 1999. A framework for understanding accelerated international entrepreneurship. Research in Global Strategic Management 7, 23-40.

Oviatt, B., McDougall, P., 2005. Defining International Entrepreneurship and Modeling the Speed of Internationalization. Entrepreneurship Theory and Practice 29 (5), 537-554.

Peretto, P., Smulders, S., 2002. Technological distance, growth and scale effects. Economic Journal 112 (481), 603-624.

Prashantham, S., Dhanaraj, C., 2010. The Dynamic Influence of Social Capital on the International Growth of New Ventures. Journal of Management Studies 47 (6), 967-994.

Puthusserry, P., Child, J., Rodrigues., S.B. 2014. Psychic Distance, its Business Impact and Modes of Coping: A Study of British and Indian Partner SMEs. Management International Review 54 (1), 1-29.

Ragozzino, R. 2009. The Effects of Geographical Distance on the Foreign Acquisition Activity of U.S. Firms. Management International Review 49 (4), 509-535.

Rothaermel, F.T., Kotha, S., Steensma, H.K., 2006. International Market Entry by U.S. Internet Firms: An Empirical Analysis of Country Risk, National Culture, and Market Size. Journal of Management 32 (1), 56-82.

Schwens, C., Eiche, J., Kabst, R. 2011. The Moderating Impact of Informal Institutional Distance and Formal Institutional Risk on SME Entry Mode Choice. Journal of Management Studies 48 (2), 330-351.

Schwartz, S.H. 1994. Are there universal aspects in the content and structure of values? Journal of Social Issues 50, 19-45.

Schwartz, S.H. 1999. A Theory of Cultural Values and Some Implications for Work. Applied Psychology 48 (1), 23-47. 
Shenkar, O. 2001. Cultural Distance Revisited: Towards a More Rigorous Conceptualization and Measurement of Cultural Differences. Journal of International Business Studies 32 (3), 519-535.

Shenkar, O., Luo, Y., Yeheskel, O., 2008. From "distance" to "friction": substituting metaphors and redirecting intercultural research. Academy of Management Review 33 (4), 905-923.

Sousa, C.M.P., Bradley, F., 2006. Cultural Distance and Psychic Distance: Two Peas in a Pod? Journal of International Marketing 14 (1), 49-70.

Sousa, C.M.P., Lages, L.F. 2011. The PD scale: a measure of psychic distance and its impact on international marketing strategy. International Marketing Review 28 (2), 201-222.

Stoelhorst, J.W. 2008. The explanatory logic and ontological commitments of generalized Darwinism. Journal of Economic Methodology 15 (4), 343-363.

Sullivan, D. 1994. Measuring the degree of internationalization of a firm. Journal of International Business Studies 25, 493-513.

Stöttinger, B., Schlegelmilch, B.B. 2000. Psychic distance: a concept past its due date? International Marketing Review 17 (2), 169-173.

Tallman, S., Li, J., 1996. Effects of international diversity and product diversity on the performance of multinational firms. Academy of Management Journal 39 (1), 179-196.

Terpstra V., Yu, C-M., 1988. Determinants of foreign investment of U.S. advertising agencies. Journal of International Business Studies 19 (1), 33-46.

Tihanyi, L., Griffith, D.A., Russell, C.J., 2005. The effect of cultural distance on entry mode choice, international diversification, and MNE performance: a meta-analysis. Journal of International Business Studies 36 (3), 270-283. 
Tovstiga, G., Hamer, P., Popova, V.A., Efimov, I.P., Moskalev, S.V., Bortnik, I.M. 2004. Preparing Russian Small Innovative Enterprises for International Competitiveness: A Scoping Study. Journal of International Entrepreneurship 2 (1-2), 89-108.

Vachani, S. 2005. Problems of foreign subsidiaries of SMEs compared with large companies. International Business Review 14 (4), 415-439.

Williams, J.P. 2006. Authentic Identities: Straightedge Subculture, Music, and the Internet. Journal of Contemporary Ethnography 35 (2), 173-200.

Wright, M., Westhead, P., Ucbasaran, D., 2007. Internationalization of Small and Mediumsized Enterprises (SMEs) and International Entrepreneurship: A Critique and Policy Implications. Regional Studies 41 (7), 1013-1029.

$\mathrm{Xu}, \mathrm{D}$., Shenkar, O., 2002. Institutional distance and the multinational enterprise. Academy of Management Review 27 (4), 608-618.

Yu, J., Gilbert, B.A., Oviatt, B.M., 2011. Effects of alliances, time, and network cohesion on the initiation of foreign sales by new ventures. Strategic Management Journal 32, 424446. 